\title{
U-Pb DATING OF A REMAGNETIZED PALEOZOIC LIMESTONE
}

\author{
Charles P. DeWolf and Alex N. Halliday
}

Department of Geological Sciences, University of Michigan

\begin{abstract}
The Upper Ordovician Trenton Group of New York State is one of a number of Appalachian limestones which yields paleomagnetic poles suggesting disturbance in the late Paleozoic. Calcite fractions dissolved from samples of the Trenton Limestone define a ${ }^{238} \mathrm{U}-206 \mathrm{~Pb}$ age of $454 \pm 8 \mathrm{Ma}$ (MSWD = 12.8) in excellent agreement with ${ }^{40} \mathrm{Ar}-{ }^{39} \mathrm{Ar}$ and $\mathrm{U}-\mathrm{Pb}$ ages for the deposition of the underlying Diecke Bentonite. This requires that the U-Pb system in the calcite has been preserved since deposition and early diagenesis. If late Paleozoic remagnetization of this limestone was induced by fluids, these fluids did not interact with significant amounts of carbonate. The apparent robustness of the $\mathrm{U}-\mathrm{Pb}$ system, and the large spread in $\mu$ values (18.17 -118.8), offers potential precision of $\pm 1 \mathrm{Ma}$ in determining the Paleozoic time scale.
\end{abstract}

\section{Introduction}

The direct absolute dating of the deposition and diagenesis of sedimentary rocks has long proved one of the most challenging problems in radiogenic isotope geochemistry. Previous work in this field has been concentrated on attempts to date the growth of fine grained authigenic feldspar and clays in clastic sedimentary rocks (e.g. Hearn and Sutter, 1985; Elliot and Aronson, 1987). While the high ${ }^{238} \mathrm{U} /{ }^{204} \mathrm{~Pb}$ of seawater (Broecker and Peng, 1982) and of some limestones (Doe, 1970) has long been known, only recently have studies indicated the potential of $\mathrm{Pb}-\mathrm{Pb}$ and $\mathrm{U}-\mathrm{Pb}$ dating techniques for determining depositional and diagenetic ages for carbonates (Moorbath et al., 1987; Hoff and Jameson, 1989; Smith and Farquhar, 1989; Jahn et al., 1990). This work has been of three types. Moorbath et al. and Jahn et al. have performed whole-rock leaching experiments and have determined $\mathrm{Pb}-\mathrm{Pb}$ isochrons. These studies have demonstrated the potential of $\mathrm{Pb}-\mathrm{Pb}$ dating of carbonates, but have suffered from the lack of independent constraints on the actual timing of deposition or disturbance. On the other hand, Smith and Farquhar separated out fossil components from a well studied sedimentary sequence of Paleozoic age, but found a large scatter relative to the spread in $\mu$ values. Hoff and Jameson, using whole-rock leaches, determined $\mathrm{a} \mathrm{Pb}-\mathrm{Pb}$ dolomitization age which they were able to relate to the age of an overlying unconformity.

Our purpose in this study was to investigate the robustness of the U-Pb system by studying a limestone with a well known depositional age and a supposed disturbance that was late enough that we could resolve it from deposition, given the spread in $\mathrm{U} / \mathrm{Pb}$ ratios observed in these previous studies. The late Ordovician Trenton Group of New York State fit these criteria, as paleomagnetic studies yield late Carboniferous to Permian poles (McCabe et al., 1984), supposedly due to fluid movements and growth of authigenic

\section{Copyright 1991 by the American Geophysical Union}

Paper number 91GL01278

0094-8534/91/91GL-01278\$3.00 minerals during the Alleghanian Orogeny. In addition, the depositional age is particularly well determined due to several recent geochronological studies of Ordovician bentonites (Kunk and Sutter, 1984; Samson et al., 1989; Tucker et al., 1990).

The Trenton Group of New York State is a sequence of late Ordovician limestones deposited just prior to the Taconic Orogeny. In the vicinity of Watertown, NY, where the samples were collected, the formations of the Trenton Group consist of alternating lower subtidal and below wave base facies (Fisher, 1977). The Trenton Group is well defined paleontologically and forms the basis for the Trentonian Stage, part of the type section for the North American Ordovician Series. The Diecke Bentonite can be correlated over much of North America (Kolata et al., 1987) and separates the Blackriver and Trenton Stages (Sloan, 1987) This bentonite has been dated at $454 \pm 6 \mathrm{Ma}$ using the ${ }^{40} \mathrm{Ar}-$ ${ }^{39} \mathrm{Ar}$ technique on biotite (Kunk and Sutter, 1984) and at $457 \pm 1 \mathrm{Ma}$ using U-Pb dating of zircons (Samson et al., 1989). In addition, a $\mathrm{U}-\mathrm{Pb}$ zircon age on a bentonite from the Decorah Formation of Missouri places the Rocklandian Stage at $453.7 \pm 1.8$ (Tucker et al., 1990). These new high precision ages are in agreement with the most recent time scales (Harland, 1982; Haq and van Eysinga, 1988).

The late Paleozoic paleomagnetic poles obtained from the Trenton Group are similar to those found in many Appalachian limestones and have been proposed to result from the expulsion of fluids from deeply buried sediments during the Alleghanian Orogeny (300-250 Ma) (Oliver, 1986; Miller and Kent, 1988), resulting in the formation of new magnetite in limestones along the continental margin. There is independent scattered evidence for Alleghanian disturbances through much of the Appalachian Basin (Hearn and Sutter, 1985; Hearn et al., 1987).

\section{Methods}

Five samples from a single outcrop of the Trenton Group in the Watertown (NY) area were collected by D. Suk (University of Michigan) for paleomagnetic investigation, in which the previously determined late Paleozoic remagnetization was confirmed. Approximately 5 grams of sample was taken from the sides of the drill cores for this study. All five samples used are grainstones with abundant fossil fragments of ostracods, crinoids and trilobites and a few brachiopods, and are composed of more than $95 \%$ calcite (except for sample 6.4 which is $85 \%$ calcite). Irregular patches and veinlets of dolomite make up most of the remaining material. Trace amounts of $K$-feldspar, quartz and pyrite were identified using SEM and cathodoluminescence. All samples show a pervasive orange luminescence indicative of the incorporation of $\mathrm{Mn}^{+2}$ during recrystallization under reducing conditions. Almost all crinoid and trilobite fragments are recrystallized with some crinoids showing subgrain domains and syntaxial overgrowths of luminescent calcite. The ostracods and brachiopods are generally nonluminescent but are rimmed by syntaxial overgrowths of luminescent calcite as well. The dolomite veinlets appear to 
be last in the paragenetic sequence. All these observations combined indicate that the samples have undergone a thorough diagenesis and alteration, and therefore, the U-Pb ages may be expected to date this process.

Approximately $100 \mathrm{mg}$ of crushed sample was washed successively with five $1 \mathrm{ml}$ aliquots of ultrapure water. The calcite fraction was then dissolved in $5 \mathrm{ml}$ of $10 \%$ acetic acid, the solution removed, centrifuged for 10 minutes, then split for spiking with a mixed ${ }^{235} \mathrm{U}-208 \mathrm{~Pb}$ tracer. Acetic acid was chosen for dissolution based on prior leaching experiments that showed reproducible isotopic ratios at acid strengths less than $1 \mathrm{~N} \mathrm{HCl}$. Acid strengths greater than $1 \mathrm{~N} \mathrm{HCl}$ yielded variable isotopic compositions, presumably due to partial dissolution of the residue phases (primarily dolomite). The residues were washed in ultrapure water, dissolved sequentially in $\mathrm{HF}, \mathrm{HNO}_{3}$, and $\mathrm{HCl}$ and split and spiked in the same manner. $\mathrm{Pb}$ and $\mathrm{U}$ were separated using standard anion exchange techniques. Isotopic analyses were made at the University of Michigan using a VG Sector mass spectrometer equipped with seven Faraday collectors in the same plane. The level of organic components was checked routinely and monitored during runs by measuring mass 205 . The ratio of mass 205 to mass 204 was less than $5 \times 10^{-4}$. All $\mathrm{U}$ and $\mathrm{Pb}$ analyses were corrected for fractionation (0.11\% per a.m.u.) by repeated analyses of NBS 981 and U500 standards. ${ }^{238} \mathrm{U} / 204 \mathrm{~Pb}$ are accurate to better than $0.2 \%$. Total process blanks were less than $150 \mathrm{pg}$ for $\mathrm{Pb}$ and less than $20 \mathrm{pg}$ for $\mathrm{U}$.

\section{Results}

$\mathrm{U}$ and $\mathrm{Pb}$ concentrations and isotopic compositions are given in Table 1. These absolute concentrations are precise only to about $10 \%$ due to weighing uncertainties and the difficulty of quantitative removal of the solution from the residues prior to spiking. In all samples, the bulk of the $\mathrm{Pb}$

TABLE 1. U AND Pb CONCENTRATIONS AND ISOTOPIC COMPOSITIONS OF TRENTON GROUP WHOLE ROCK LEACHES AND RESIDUES.

\begin{tabular}{ccccccc}
\hline \multirow{2}{*}{ SAMPLE } & $\begin{array}{c}\mathrm{Pb} \\
{[\mathrm{ppm}]}\end{array}$ & $\begin{array}{c}\mathrm{U} \\
{[\mathrm{ppm}]}\end{array}$ & $\begin{array}{r}238 \mathrm{U} \\
204\end{array}$ & $\begin{array}{c}206 \mathrm{~Pb} \\
204\end{array}$ & $\begin{array}{c}207 \mathrm{~Pb} \\
204\end{array}$ & $\begin{array}{c}208 \mathrm{~Pb} \\
204\end{array}$ \\
\hline $6.2 \mathrm{~A}$ & 0.64 & 0.18 & 18.17 & 20.006 & 15.718 & 39.708 \\
$6.2 \mathrm{R}$ & 1.73 & 0.08 & 2.99 & 18.688 & 15.646 & 38.942 \\
$6.3 \mathrm{~A}$ & 1.06 & 0.37 & 22.83 & 20.480 & 15.739 & 40.014 \\
$6.3 \mathrm{R}$ & 5.45 & 0.59 & 7.01 & 18.838 & 15.626 & 38.881 \\
$6.4 \mathrm{~A}$ & 0.31 & 0.20 & 43.78 & 21.939 & 15.877 & 39.323 \\
$6.5 \mathrm{~A}$ & 0.28 & 0.43 & 111.06 & 26.797 & 16.204 & 40.401 \\
$6.5 \mathrm{D}$ & 0.15 & 0.24 & 118.80 & 27.440 & 16.178 & 40.311 \\
$6.5 \mathrm{R}$ & 0.99 & 0.06 & 3.81 & 18.675 & 15.665 & 38.629 \\
\hline A11 & & &
\end{tabular}

All isotopic compositions are corrected for mass fractionation $(0.10 \%)$ based on analyses of NBS 981 . The within run uncertainties are less than $0.2 \%$ for all samples. The uncertainty in $\mu$ is estimated at $0.3 \%$ estimated from the reproducibility of NBS $U 500$, and uncertainty in the ${ }^{235} \mathrm{U} /{ }^{208} \mathrm{~Pb}$ value of the spike. The sample designations $\mathrm{A}$ signifies acetic acid leach, $\mathbf{R}=$ corresponding residue. Sample $6.5 \mathrm{D}$ is from a second leaching of sample 6.5. Concentrations of $\mathrm{U}$ and $\mathrm{Pb}$ are reported relative to the total mass of sample, which was greater than $95 \%$ calcite in all samples except 6.4 , which was $80 \%$ calcite.

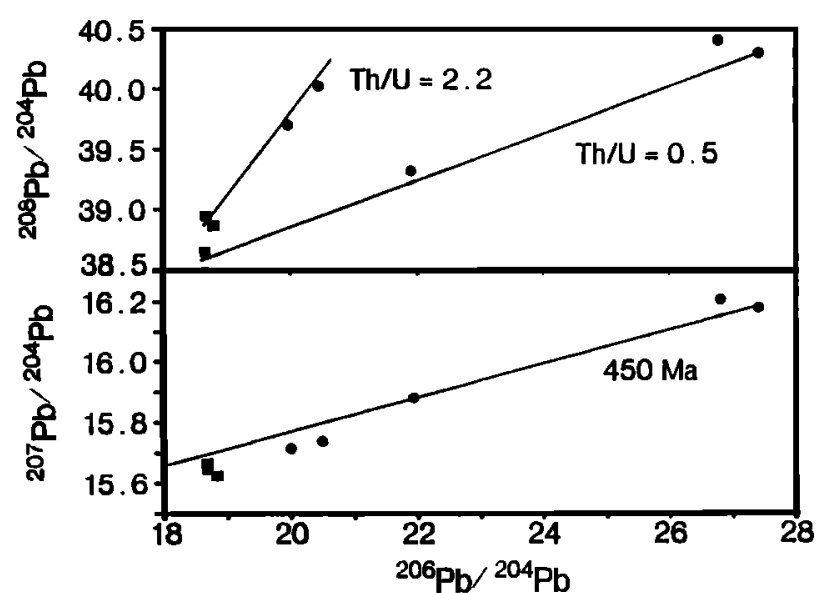

Fig. 1. $\mathrm{Pb}$ isotope correlation plots for leaches and residues from the Trenton Group. Symbols are as follows: Circles, calcite; squares, residues of dolomite with subordinate pyrite, K-feldspar, and quartz. The $450 \mathrm{Ma}$ line in the lower diagram is a reference line corresponding to the depositional age and ${ }^{238} \mathrm{U}-206 \mathrm{~Pb}$ age. Constraints on $\mathrm{Th} / \mathrm{U}$ ratios are calculated by assuming that the residue isotopic composition approximates the initial composition of the leaches (see text). Analytical uncertainties are one-fifth the size of the symbols.

resides in the residues. While the residues are primarily dolomite, trace amounts of $\mathrm{K}$-feldspar and pyrite are seen in thin section, and may contribute significantly to the $\mathrm{Pb}$ budget of the residue. The calcite fractions contain relatively large amounts (175 ppb - $429 \mathrm{ppb}$ ) of $\mathrm{U}$ and resulting $238 \mathrm{U} / 204 \mathrm{~Pb}$ values range from 18.17 to 118.8 . Three ages can be calculated from these data. The calcite fractions yield $235 \mathrm{U}-$ ${ }^{207} \mathrm{~Pb}$ and ${ }^{207} \mathrm{~Pb}-206 \mathrm{~Pb}$ ages of $537 \pm 40 \mathrm{Ma}(\mathrm{MSWD}=8.58$; not shown) and $844 \pm 100$ (MSWD = 9.68; Figure 1), respectively. The large MSWD and these unrealistic ages are interpreted to indicate that these systems have been affected by either original heterogeneity or later disturbance.

In contrast, the calcites lie along a ${ }^{238} \mathrm{U}-206 \mathrm{~Pb}$ isochron (technically an "errorchron") corresponding to an age of 454 \pm 8 Ma $2 \sigma$ (MSWD=12.8; Figure 2). While the large MSWD indicates some scatter beyond than that due to analytical precision, this age is in good agreement with the ages determined for the Diecke Bentonite (454 $\pm 6 \mathrm{Ma}$, Kunk and Sutter, 1984; $457 \pm 1 \mathrm{Ma}$, Samson, 1989). We interpret this age to be the time of diagenesis. This represents the first reported ${ }^{238} \mathrm{U}-206 \mathrm{~Pb}$ age on calcites separated from whole rock limestones. Since the samples show clear evidence for diagenetic alteration, we interpret this age to indicate that diagenesis was complete shortly after deposition, and that the calcite fraction acted as a nearly closed system since that time. This requires that $\mathrm{U}$ and $\mathrm{Pb}$ in the calcite were not remobilized during the Alleghanian Orogeny. This closed system behavior is most easily reconciled with $\mathrm{U}$ and $\mathrm{Pb}$ being incorporated within the calcite structure, rather than adsorbed together with iron oxide coatings along grain boundaries (Liu et al., 1988).

The disparity between the ${ }^{207} \mathrm{~Pb}-206 \mathrm{~Pb}$ and ${ }^{235} \mathrm{U}-207 \mathrm{~Pb}$ ages and the ${ }^{238} \mathrm{U}-206 \mathrm{~Pb}$ age is significant, since in a true closed system initially in isotopic equilibrium, these ages should agree. Possible sources of this discrepency include initial isotopic heterogeneity, late disturbance, or the mixing of detrital material during the leaching process. The latter is unlikely given results of earlier leaching experiments, and because the scatter occurs even among the most radiogenic 


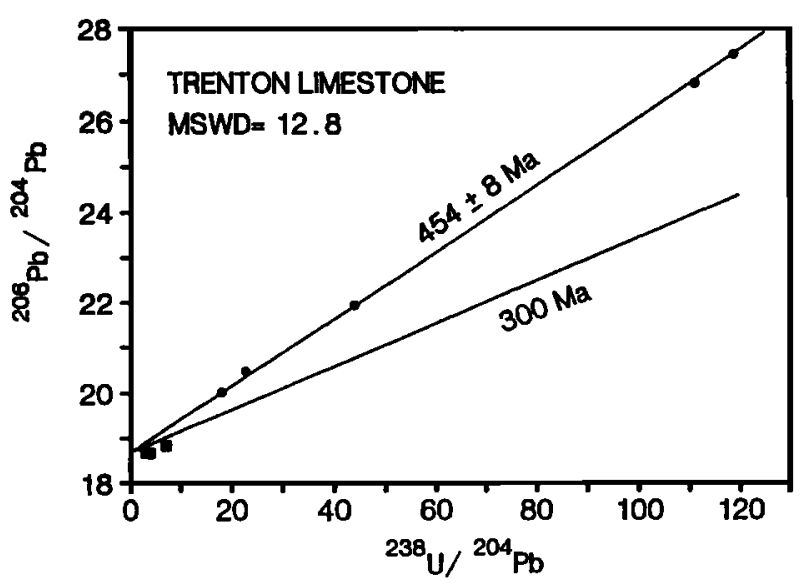

Fig. 2. ${ }^{238} \mathrm{U}-206 \mathrm{~Pb}$ isochron diagram for the Trenton Group samples. Regression of the calcite data (circles) using the technique of York (1969) yields an age of $454 \pm 8 \mathrm{Ma}(2 \sigma$; MSWD=12.8). The residues (squares) were not included in the regression. The $300 \mathrm{Ma}$ reference line corresponds to the remagnetization age for sedimentary rocks of the northern Appalachians (Miller and Kent, 1988). Analytical uncertainties $(0.2 \%)$ are one-fifth the size of the symbols.

samples which can not contain significant amounts of unradiogenic residue $\mathrm{Pb}$. Heterogeneity in initial $\mathrm{Pb}$ isotopic composition is expected due to the short residence of $\mathrm{Pb}$ in seawater (Broecker and Peng, 1982). The isotopic composition of $\mathrm{Pb}$ dissolved in seawater or scavenged by the shelf carbonates will be greatly sensitive to changes in local detrital fluxes and will not be buffered by the global ocean. The short residence time of $\mathrm{Pb}$ also predicts near isotopic equilibrium between detrital and dissolved components. Figures 1 and 2 show that the residues (which contain some $\mathrm{Pb}$ in K-feldspar) do lie very close to the "isochrons" defined by the calcite fractions. However, in detail, the residues lie at slightly lower $207 \mathrm{~Pb} / 204 \mathrm{~Pb}$ (Figure 1), indicating some source heterogeneity. Thus, $\mathrm{Pb}$ with slightly variable isotopic composition may be incorporated into carbonate either as a result of variations in source with time, or exchange of $\mathrm{Pb}$ with detrital phases during diagenetic recrystallization. Such variation would have a greater effect on $207 \mathrm{~Pb}-206 \mathrm{~Pb}$ and $235 \mathrm{U}-207 \mathrm{~Pb}$ ages since in situ production of ${ }^{207} \mathrm{~Pb}$ will be very small compared to in situ production of $206 \mathrm{~Pb}$. This limitation of the use of the $235 \mathrm{U}-$ $207 \mathrm{~Pb}$ decay scheme in Phanerozoic limestones has been discussed previously (Smith and Farquhar, 1989). In the case of the Trenton Group, $\mathrm{Pb}$ fluxes would be expected to change as arc-derived sediment encroached from the east during the Taconic Orogeny.

A second possible cause of initial $\mathrm{Pb}$ isotopic heterogeneity is the incorporation of detrital $\mathrm{Pb}$, remobilized during diagenesis and precipitated in diagenetic carbonate. This is suggested by the displacement of the ${ }^{207} \mathrm{~Pb} / 204 \mathrm{~Pb}$ ratios of the less radiogenic calcites toward those of the residues. The samples with lower ${ }^{207} \mathrm{~Pb} / 204 \mathrm{~Pb}$ also show a distinct trend in $208 \mathrm{~Pb} / 204 \mathrm{~Pb}$ (Figure 1). In this scenario, the diagenetic fluids that precipitated the $\mathrm{K}$-feldspar and/or dolomite also recrystallized some of the calcite. Such fluids would have had a ${ }^{207} \mathrm{~Pb} /{ }^{204} \mathrm{~Pb}$ which was slightly lower than the ${ }^{207 \mathrm{~Pb}} / 204 \mathrm{~Pb}$ of the carbonate that originally precipitated from seawater. However, the subsequent development of the ${ }^{238} \mathrm{U}-206 \mathrm{~Pb}$ isochron requires that this occurred very shortly after deposition.
While there appear to have been some differences in initial $\mathrm{Pb}$ isotopic composition between calcites and residues, constraints can be placed on approximate $\mathrm{Th} / \mathrm{U}(\kappa)$ ratios in the calcites by assuming that the calcite fraction and residue fraction have the same initial $\mathrm{Pb}$ isotopic composition and that the residues have both low $\mathrm{U} / \mathrm{Pb}$ and $\mathrm{Th} / \mathrm{Pb}$. Measured $\mathrm{U} / \mathrm{Pb}$ for the residues are indeed low (Table 1). As a result, present day isotopic compositions of the residues should approximate initial isotopic compositions of the calcites. Th/U ratios estimated in this manner range from 0.5 to 2.0 and are clearly not uniform. This spread in $\mathrm{Th} / \mathrm{U}$ ratios is similar to that observed in previous studies of whole rock limestones and corals (Smith and Farquhar, 1989; Liu et al., 1988). Thorium concentrations, estimated from calculated $\mathrm{Th} / \mathrm{Pb}$ and $\mathrm{Pb}$ concentrations vary by a factor of three, and are intermediate between the variation in $\mathrm{Pb}$ concentration and that in $U$ concentration. This suggests variable incorporation of both $T h$ and $U$ in the samples analyzed in this study. Variable $U$ incorporation could result from a variation in redox conditions accompanying the crystallization of calcite during deposition and diagenesis (Liu et al., 1988).

The combination of a preserved depositional $\mathrm{U}-\mathrm{Pb}$ age and reset magnetic poles indicates that calcite was not recrystallized during the remagnetization event. These results are consistent with the production of magnetite via oxidation of pyrite as observed by Suk et al., 1990, as this reaction most likely requires slightly alkaline conditions (Garrels and Christ, 1965). The paleomagnetic data underline the robustness of the $\mathrm{U}-\mathrm{Pb}$ system in limestones, and hence the potential of the technique in geochronology.

\section{Conclusions}

$\mathrm{U}-\mathrm{Pb}$ dating of the Trenton Group yields an age of $454 \pm 8$ $\mathrm{Ma}$ in excellent agreement with ages determined on the underlying Deicke Bentonite. We interpret this as dating the end of carbonate diagenesis, which apparently occurred very soon after deposition. The U-Pb systematics show no evidence for disturbance during the late Paleozoic. If these rocks were affected by regional fluid migration at that time, those fluids did not affect the carbonate portion of the rock even though this constitutes $95-99 \%$ of the rock.

This study presents further evidence that the U-Pb system can provide reliable depositional ages on limestones. However, as also pointed out here, Phanerozoic ${ }^{207} \mathrm{~Pb}-$ ${ }^{206} \mathrm{~Pb}$ and $235 \mathrm{U}-207 \mathrm{~Pb}$ ages need to be interpreted with caution as initial heterogeneity may be large relative to in situ growth of ${ }^{207} \mathrm{~Pb}$. In addition to the results presented here, we have determined $\mu$ values for other limestone samples of varying lithology, and found similarly large ranges. It appears that $\mu$ values ranging between 20 and 120 are common. This range allows potential precision of $\pm 1 \mathrm{Ma}$ for limestones of early Paleozoic age. Greater uncertainties reported here and in other studies published thus far seem to be limited by scatter caused by heterogeneity in initial $\mathrm{Pb}$ isotopic composition, and in some cases by late disturbance. Precision of \pm 1 Ma could lead to considerable refinement of the Paleozoic time scale, and would be an important tool for the correlation of Proterozoic stratigraphy for which biostratigraphic correlation is largely impossible.

Acknowledgements. The authors would like to thank Klaus Mezger, Rob van der Voo, Paul Taylor, Bor-ming Jahn and four anonymous reviewers for their helpful comments. We also gratefully acknowledge the Scott Turner Fund for support of this project. 


\section{References}

Broecker, W.S., and Peng, T.H., Tracers in the Sea, 690 pp., Eldigio, New York, 1982.

Elliot, W.C., and Aronson, J.L., Alleghenian episode of Kbentonite illitization in the southern Appalachian Basin. Geology 8. 735-730, 1987.

Garrels R.M., and Christ, C.L., Solutions. Minerals and Equilibria, Freeman, San Francisco, 1965.

Haq, B.U. and van Eysinga, F.W.B., Geologic time table, 4th ed, Elsevier, Amsterdam, 1988.

Harland, W.B., Cox, A.V., Llewellyn, P.G., Pickton, C.A.G., Smith, A.G., and Walters, R. A., Geologic Time Scale Cambridge University Press, Cambridge, 1982.

Hearn, P.P., and Sutter, J.F., Authigenic potassium feldspar in Cambrian carbonates: evidence of Alleghenian brine migration, Science, 228, 1529-1531, 1985.

Hearn, P.P., Sutter, J.F., and Belkin, H.E., Evidence for Late Paleozoic brine migration in Cambrian carbonate rocks of the central and southern Appalachians: Implications for Mississippi Valley-type sulfide mineralization, Geochim. Cosmochim. Acta.. 51, 1323. 1334, 1987.

Hoff, J. A., and Jameson, J., Timing of uranium enrichment in dolostones from the Wahoo Formation, subsurface, Prudhoe Bay, Alaska, Geol. Soc. Am. Abs. w. Prog., 16, 1989.

Jackson, M., McCabe, C., Ballard, M.M., and Van der Voo, R., Magnetite authigenesis and diagenetic paleotemperatures across the northern Appalachian basin. Geology, 16. 592-595, 1988.

Jahn, B.M., Bertrand-Sarfati, J., Morin, N., and Mace, J., Direct dating of stromatolitic carbonates from the Schmidtsdrif Formation (Transvaal Dolomite), South Africa, with implications on the age of the Ventersdorp Supergroup. Geology, 18, 1211-1214, 1990.

Kolata, D.R., Frost, J.K., and Huff, W.D., Chemical correlation of K-bentonite beds in the Middle Ordovician Decorah Subgroup, upper Mississippi Valley, Geology, $15,208-211,1987$.

Kunk, M.J., and Sutter, J.F., ${ }^{40} \mathrm{Ar}-{ }^{39} \mathrm{Ar}$ age spectrum dating of biotite from Middle Ordovician bentonites, eatern North America, in Bruton, D.L. Aspects of the Ordovician system: Oslo University Paleontological Contributions 295, 11-12, 1984.

Liu, Y.G., Miah, M.R., and Schmitt, R.A., Cerium: a chemical tracer for paleo-oceanic redox conditions.
Geochim. Cosmochim. Acta., 52, 1361-1371, 1988.

McCabe, C., Van der Voo, R., and Ballard, M.M., Late Paleozoic remagnetization of the Trenton Limestone, Geophys. Res. Lett. 11, 979-982, 1984.

Miller, J.D. and Kent, D.V., Regional trends in the timing of Alleghanian remagnetization in the Appalachians, Geology, 16, 588-591, 1988.

Moorbath, S., Taylor, P.N., Orpen, J.L., Treloar, P., and Wilson, J.F., First direct radiometric dating of Archaean stromatolitic limestone, Nature, 326, 865-867, 1987.

Oliver, J., Fluids expelled tectonically from orogenic belts: Their role in hydrocarbon migration and other geologic phenomena, Geology, 14, 99-102, 1986.

Samson, S.D., Patchett, P.J., Roddick, J.C., and Parrish, R.R. Origin and tectonic setting of Ordovician bentonites in North America: isotopic and age constraints. Geol. Soc. Am. Bull. 101, 1175-1181, 1989.

Sloan, R.E., Tectonics, biostratigraphy and lithostratigraphy of the Middle and Late Ordovician of the upper Mississippi Valley, in Sloan, R.E. ed, Middle and Late Ordovician lithostratigraphy and biostratigraphy of the upper Mississippi Valley, Minn. Geol. Surv. Rep. Invest., 35, 7-20, 1987.

Smith P.E., and Farquhar, R.M., Direct dating of Phanerozoic sediments by the $238 \mathrm{U} / 206 \mathrm{~Pb}$ method, Nature, 341, 518-521, 1989.

Suk, D., Van der Voo, R., and Peacor, D.R., Replacement of pyrite framboids by magnetite in limestone and implications for paleomagnetism, Nature, 345, 611$633,1990$.

Tucker, R.D., Krogh, T.E., Ross, R.J., and Williams, S.H., Time-scale calibration by high-precision U-Pb zircon dating of interstratified volcanic ashes in the Ordovician and Lower Silurian stratotypes of Britain. Earth Planet. Sci. Lett. 100, 51-58, 1990.

York D., Least squares fitting of a straight line with correlated errors. Earth Planet. Sci. Lett. 5, 320-324, 1969.

C.P. DeWolf and A.N. Halliday, Department of Geological Sciences, University of Michigan, Ann Arbor, MI 481091063.
Received: January 22, 1991;

Revised: April 18, 1991;

Accepted: May 1, 1991. 